\title{
MENGUKUHKAN ISLAM NUSANTARA: KAJIAN SOSIOLOGIS-HISTORIS
}

\author{
Hawwin Muzakki \\ Dosen IAIN Ponorogo \\ hawwin100@gmail.com
}

\section{Abstract}

Islam bring the message as a religion of "rohmatan lil 'alamin". However, post-prophetic Islam turned into ideological extremism. The author will focus the discussion with the formulation of the problem: How does the process of changing Islam from rohmatan lil 'alamin become an ideology through sociological-historical analysis? How to restore Islam to be a rohmatan lil 'alamin for future Islamic development through sociological-historical analysis? The purpose of this discussion to trace the transformation of Islamic into ideology and explores Islam rahmatan lil alamin in Indonesia, for moderate vision of Islam Nusantara. The author will discuss using the theory of social construction (externalization, objectivity, internalization) by Peter L. Berger. The results revealed that, externally Islam brought by the Prophet Mubammad brought the teaching of rohmatan lil'alamin. The rohmatan lil 'alamin value is objectified by the Arabic characteristic of the ashobiyah. The ashobiyah nature of the Arab nation is internalized into society through ideological extremities. To restore Islam rohmatan lil alamin, the writer review Islam Nusantara. Islam is externalized in Indonesia through peaceful way. Islamic teachings finally objectified by the plural Indonesian society and influenced "Ethical Java". Plural nature and maintain harmony in the ethics of Java is embedded character of moderation values (Tawassuth, Tawâzun, I'tidâl, Tasâmuh). This research contributes, to the development of Nusantara Islam which is a model of Islam that is not only centered on Arabia and realize Islam that preach rahmatan lil 'alamin. 
Keywords: Islam Nusantara, Externalization, Objectivity and Internalization

\section{A. PENDAHULUAN}

Islam menyebar luas di Arab setelah Nabi Muhammad diangkat menjadi Rasul di umur 40 tahun. Setelah kurang lebih 12 Tahun Rasul berdakwah di Makkah dilaluinya dengan berbagai rintangan, mulai mengahadapi ejekan, cemoohan, percobaan pembunuhan, dikatakan tukang sihir dan masih banyak lagi yang lain akhirnya Rasul memutuskan untuk hijrah di kota Madinah. Disana beliau selama 10 Tahun berhasil menancapkan ajaran-ajaran inti Islam dengan sangat baik. Puncaknya pada masa fathul Makkah, Rasul berhasil menyatukan Makkah dan Madinah dalam agama Islam dengan jalan damai. Islam berasal dari kata salam yang artinya selamat, dengan kesan memberikan pesan damai kepada seluruh masyarakat di dunia. Satu lagi wajah Islam datang dengan membawa pesan sebagai agama yang rohmatan lil '́alamin (rahmat bagi seluruh alam).

Penyebaran agama Islam langsung meluas begitu cepat sampai ke penjuru dunia. Disebarkan secara bertahap oleh umat Nabi Muhammad mulai periode khulafaurrasyidin, munculnya beberapa dinasti Islam semisal Bani Umayyah, bani Abbasiyah, Dinasti Syafawi, Dinasti Mughol, Dinasti Turki Utsmani dan terus berkembang sampai masa ini. Penaklukan Islam di berbagai wilayah seperti di Afrika, Andalusia, India, Damaskus, dan Baghdad membuat ajaran Islam berinteraksi dengan peradaban lain yang sudah berkembang sebelumnya semisal peradaban Yunani, Persia, dan Eropa sehingga melahirkan ajaranajaran Islam dengan berbagai coraknya.

Kondisi tersebut bagai dua mata pisau, Islam tidak hanya meluas wilayahnya, namun Islam juga berubah menjadi alat konflik di sela-sela kemajuan peradabannya. Misalnya banyaknya terjadi peperangan, perebutan kekuasaan, pertumpahan darah di saat pergantian kepemimpinan, kudeta-kudeta militer, bahkan sampai kehancuran kota baghdad dan pengusiran muslim dari Andalusia, banyaknya aliran-aliran yang berkembang semisal syiah, khawarij, murjiah dan sebagainya. Islam pasca kenabian ini menjadi aliran-aliran yang diyakini oleh kelompok-kelompok Islam tertentu dan mempunyai inti ajaran yang berbeda-beda, sehingga wajah rahmatan yang ada pada masa kenabian berubah menjadi ekstrimitas-ekstrimitas konfik dengan corak yang bervariasi.

Persoalan konflik tersebut masih terus merasuki Islam di era modern ini, tentunya dengan wajah yang baru. Perubahan dari rahmat menjadi alat konflik 
yang bervariasi ini menyebar ke seluruh dunia dengan berbagai modus yang beragam pula. Misalnya Indonesia, wajah-wajah aliran-aliran ini hadir dalam bentuk Islam fundamentalis seperti Hibut Tahrir Indonesia, Jamaah Islamiyah, Jamaah Tabligh, Ikhwanul Muslimin dan seterusnya. Kaum intelektual Indonesia biasanya menyebutnya dengan aliran trans-nasionalis, aliran yang bukan berasal dari murni lokal Islam di Indonesia. Islam lokal yaitu Islam yang tumbuh dan berkembangnya menggunakan nalar lokal Indonesia dalam syariatnya, dalam memodifikasi ajaran Islam yang sumbernya dari Arab, bisa dicontohkan Nahdatul Ulama' misalnya mendapat pengaruh dari budaya Jawa dan tradisi Hindu-Budha di Indonesia sehingga kemudian muncul tradisi slametan, tahlilan, kenduri dan seterusnya. Contoh kedua misalnya Muhammadiyah dengan tokohnya $\mathrm{KH}$. Ahmad Dahlan dengan ajaran purifikasinya yang ia peroleh dari Timur dengan perpaduannya dari pengaruh lokal Indonesia, akhirnya ,menimbulkan gerakan dakwah dalam hal pendidikan mulai dari jenjang AUD sampai perguruan tinggi, mendirikan rumah sakit, mendirikan panti asuhan serta menghilangkan bid'ah, khurafar dan tahayyul yang beredar di masyarakat Indonesia.

Islam Indonesia sendiri mendapat tantangan aliran atau pemahaman Islam dari daerah Timur yang sebetulnya secara substansi rawan konflik, kepentingan dan juga ideologi tertentu. Selain itu, Islam Indonesia mendapat tantangan lain dari Barat juga membentuk wajah baru dunia Islam menjadi lebih liberal dan radikal, dengan munculnya pemikiran modern khas-khas kajian orientalis. Orientalisme terhadap dunia Islam mengubah wajah Islam di Indonesia dengan predikat Islam "bebas", berfikiran nyeleneh dan dikhawatirkan merusak aqidah Islamiyah orang Indonesia.

Aspek yang menjadi kegelisahan akademik penulis adalah, mengapa Islam yang awalnya rahmatan menjadi bentuk aliran-aliran, yang justru jauh dari rahmatan itu sendiri? Ada aspek yang tetap dan ada aspek yang berubah dalam penyebaran agama Islam? Untuk itu penulis akan memfokuskan penelitian ini pada penggunaan kolaborasi teori sosiologis-historis. Teori konstruksi sosial Peter L. Berger, secara sosiologis untuk melihat tahapan-tahapan perubahan Islam (proses internalisasi) yang rahmat menjadi Islam yang "marah". Sedangkan, dalam membahas perkembangan Islam penulis menggunakan kajian historis untuk melihat perkembangan Islam dari masa ke masa, dari Arab ke Indonesia, dari teks ke konteks, dan untuk melihat yang tetap dan berubah.

Sebagai fokus kajian dalam makalah ini, dengan sub rumusan masalah: Pertama, bagaimana perubahan wajah Islam dari wajah rahmatan menjadi 
ideologi konflik, melalui kajian analisis sosiologis-historis? Kedua, bagaimana mengembalikan Islam menjadi rahmatan untuk pengembangan Islam masa depan di Nusantara, melalui kajian analisis sosiologis-historis? Tujuan dari rumusan masalah yang pertama adalah menelusuri perubahan agama Islam yang rahmatan menjadi agama yang "marah". Tujuan dari pembahasan sub rumusan masalah yang kedua adalah mengeksplorasi Islam yang rahmatan lil alamin untuk visi moderat Islam nusantara.

Untuk membahas dari rumusan masalah di atas, penulis akan membahas dengan pendekatan sosiologis-historis, memanfaatkan berfikir sejarah secara kronologis berdasarkan urutan waktu, serta menggunakan tokoh sosiologi Peter L. Berger dengan teori konstruksi sosial. Teori ini dianalisis lebih jauh dengan argumen Ibn Kholdun dengan teori Ashobiyah untuk menggali awal sejarah arab pasca kenabian yang mengubah wajah Islam yang rahmatan lil'alamin menjadi wajah "marah". Kemudian menggali nilai-nilai Islam Nusantara melalui argumen etika jawa untuk mengembalikan Islam menjadi agama yang rohmatan lil'alamiin, untuk mencari sesuatu yang tetap dan sesuatu yang berubah dalam Islam.

\section{B. METODE}

\section{Teori Konstruksi Sosial Peter L. Berger}

Turunnya agama bersama dengan ajaran dan dogma di dalamnya, tidak sepenuhnya hanya merupakan aturan yang melangit, wahyu dan serba atas. Karena faktanya, seiring dengan perubahan kebudayaan, agama pun juga mengalami proses transformasi. Sebuah proses yang memungkinkan agama bisa berubah wujud menjadi radikal, moderat maupun ekstrimis. Kenyataan ini membuka kesadaran bahwa agama tidak cukup bila hanya dikaji dari satu sudut pandang ilmu, karena pada kenyataannya agama menampakkan dirinya juga sebagai suatu entitas yang tidak dapat dipisahkan dari keberadaan manusia sebagai mahluk yang beriman atau yang memberikan jawaban atau tanggapan terhadap Allah yang mewahyukan dirinya. Artinya dalam satu sisi, agama bisa juga dikaji dari aspek sosiologis dalam rangka melibatkan ilmu-ilmu lain dalam mempelajari sebuah ajaran agama. ${ }^{1}$

Pandangan Berger tersebut, memberikan pengertian bahwa konstruksi sekelompok masyarakat terhadap ajaran agama, mampu mengubah wajah baru

${ }^{1}$ Rudy Harold, "Agama dan Pembentukan Realitas dalam Pandangan Peter Ludwig Berger," Cakrawala 5, no. 1 (2016): 143. 
tentang aliran keagamaan, termasuk agama Islam. Islam hadir di Arab bukan ahistoris, bahkan ajaran-ajaran Islam banyak yang masih mempertahankan tradisi masyarakat Arab sekitar. Artinya, Nabi Muhammad tidak seluruhnya membawa ajaran baru yang menghilangkan tradisi sekitar. Tradisi yang baik diambil dan direkonstruksi, sedangkan tradisi yang buruk di ganti dengan ajaran yang lebih baik (dekonstruksi).

Menurut Berger dan Luckmann, terdapat dua obyek pokok realitas yang berkenaan dengan pengetahuan, yakni realitas subyektif dan realitas obyektif. Realitas subyektif berupa pengetahuan masing-masing individu. Disamping itu, realitas subyektif merupakan konstruksi definisi realitas yang dimiliki individu dan dikonstruksi melalui peoses internalisasi. Realitas subyektif yang dimiliki masing-masing individu merupakan basis untuk melibatkan diri dalam proses eksternalisasi, atau proses interaksi sosial dengan individu lain dalam sebuah struktur sosial. Melalui proses eksternalisasi itulah individu secara kolektif berkemampuan melakukan obyektivikasi dan memunculkan sebuah konstruksi realitas obyektif yang baru. ${ }^{2}$

Berger dan Luckmann mengatakan institusi masyarakat tercipta dan dipertahankan atau diubah melalui tindakan dan interaksi manusia. meskipun institusi sosial dan masyarakat terlihat nyata secara obyektif, namun pada kenyataan semuanya dibangun dalam definisi subjektif melalui proses interaksi. Obyektivitas baru bisa terjadi melalui penegasan berulang-ulang yang diberikan oleh orang lain yang memiliki definisi subyektif yang sama. Pada tingkat generalitas yang paling tinggi, manusia menciptakan dunia dalam makna simbolis yang universal, yaitu pandangan hidupnya yang menyeluruh, yang memberi legitimasi dan mengatur bentuk-bentuk sosial serta memberi makna pada berbagai bidang kehidupan. Pendek kata, Berger dan Luckmann mengatakan terjadi dialektika antara individu menciptakan masyarakat dan masyarakat menciptakan individu. Proses dialektika ini terjadi melalui eksternalisasi, objektivasi dan internalisasi. ${ }^{3}$

Teori konstruksi sosial dalam gagasan Berger mengandaikan bahwa agama sebagai bagian dari kebudayaan, merupakan konstruksi manusia, artinya terdapat proses dialektika ketika melihat hubungan masyarakat dengan agama, bahwa agama merupakan entitas yang objektif karena berada diluar

\footnotetext{
2 Margaret M.Poloma, Sosiologi kontemporer (Jakarta: Rajawali Press, 1984), 301.

3 Burhan Bungin, Konstruksi Sosial Media Massa: Kekuatan Pengaruh Media Massa, Iklan Televisi dan Keputusan Konsumen serta Kritik Terhadap Peter L. Berger \& Thomas Luckmann (Jakarta: Kencana, 2010), 14-15.
} 
diri manusia. dengan demikian agama, agama mengalami proses objektivasi, seperti ketika agama berada didalam teks atau menjadi tata nilai, norma, aturan dan sebagainya. Teks atau norma tersebut kemudian mengalami proses internalisasi kedalam diri individu, sebab agama telah diinterpretasikan oleh masyarakat untuk menjadi pedomannya. Agama juga mengalami proses eksternalisasi karena ia menjadi acuan norma dan tata nilai yang berfungsi menuntun dan mengontrol tindakan masyarakat. ${ }^{4}$

Ketika msyarakat dipandang sebagai sebuah kenyataan ganda, objektif dan subjektif maka ia berproses melalui tiga momen dialektis, yakni eksternalisasi, objektivasi, dan internalisasi. Dengan demikian, bisa dipahami bahwa realitas sosial dalam hal ini nantinya internalisasi ajaran agama Islam, merupakan hasil dari sebuah konstruksi sosial karena diciptakan oleh manusia itu sendiri. Masyarakat yang hidup dalam konteks sosial tertentu, melakukan proses interaksi secara simultan dengan lingkungannya. Dengan proses interaksi, masyarakat memiliki dimensi kenyataan sosial ganda yang bisa saling membangun, namun sebaliknya juga bisa saling meruntuhkan. Masyarakat hidup dalam dimensi-dimensi dan realitas objektif yang dikonstruksi melalui momen eksternalisasi dan objektivasi, dan dimensi subjektif yang dibangun melalui momen internalisasi. Momen eksternalisasi, objektivasi, dan internalisasi tersebut akan selalu berproses secara dialektis. Proses dialektika ketiga momen tersebut, dalam konteks ini dapat dipahami sebagai berikut: ${ }^{5}$

a. Eksternalisasi yaitu proses yang diartikan sebagai suatu proses pencurahan kedirian manusia secara terus menerus kedalam dunia, baik dalam aktivitas fisik maupun mentalnya. Termasuk penyesuaian diri dengan produk-produk sosial yang telah dikenalkan kepadanya. Produk sosial itu sendiri adalah segala sesuatu yang merupakan hasil sosialisasi dan interaksi didalam masyarakat. ${ }^{6}$ Eksternalisasi merupakan proses pengeluaran gagasan dari dunia ide ke dunia nyata. Dalam momen eksternalisasi, realitas sosial ditarik keluar individu. Didalam momen ini, realitas sosial berupa proses adaptasi dengan teks-teks suci, kesepakatan ulama, hukum, norma, nilai dan sebagainya yang hal itu berada diluar diri manusia.

4 Peter L. Berger dan Thomas Luckmann, Tafsir Sosial Atas Kenyataan: Sebuah Risalah Tentang Sosiologi Pengetahuan (Jakarta: LP3ES, 1990), 33.

5 Peter L. Berger dan Thomas Luckmann, Tafsir Sosial Atas Kenyataan: Sebuah Risalah Tentang Sosiologi Pengetahuan, 33-34.

6 Peter L. Berger dan Thomas Luckmann, 34. 
sehingga dalam proses konstruksi sosial melibatkan momen adaptasi diri atau diadaptasikan antara teks tersebut.?

b. Objektivitas. Transformasi produk-produk ini kedalam suatu dunia tidak saja berasal dari manusia, tetapi yang kemudian menghadapi manusia sebagai suatu faktasitas diluar dirinya, adalah diletakkan dalam konsep obyektivitas. Dunia yang diproduksi manusia yang berada diluar sana memiliki sifat realitas yang obyektif. ${ }^{8}$ Proses objektivasi merupakan momen interaksi antara dua realitas yang terpisahkan satu sama lain, manusia disatu sisi dan realitas sosiokultural disisi lain. kedua entitas yang seolah terpisah ini kemudian membentuk jaringan interaksi intersubyektif. Momen ini merupakan hasil dari kenyataan eksternalisasi yang kemudian mengejawantah sebagai suatu kenyataan objektif yang sui generis, unik. Pada momen ini juga ada proses pembedaan antara dua realitas sosial, yaitu realitas diri individu dan realitas sosial lain yang berada diluarnya, sehingga realitas sosial itu menjadi sesuatu yang objektif. ${ }^{9}$

c. Internalisasi adalah individu-individu sebagai kenyataan subyektif menafsirkan realitas obyektif. Atau peresapan kembali realitas oleh manusia, dan mentransformasikannya sekali lagi dari struktur-struktur dunia obyektif kedalam struktur-struktur dunia subyektif. ${ }^{10}$ Pada momen ini, individu akan menyerap segala hal yang bersifat obyektif dan kemudian akan direalisasikan secara subyektif. Internalisasi ini berlangsung seumur hidup seorang individu dengan melakukan sosialisasi. Pada proses internalisasi, setiap indvidu berbeda-beda dalam dimensi penyerapan. Ada yang lebih menyerap aspek ekstern, ada juga juga yang lebih menyerapb agian intern. Selain itu, proses internalisasi dapat diperoleh individu melalui proses sosialisasi primer dan sekunder. Adapun fase terakhir dari proses internalisasi ini adalah terbentuknya identitas. Identitas dianggap sebagai unsur kunci dari kenyataan subyektif, yang juga berhubungan secara dialektis dengan masyarakat. Identitas dibentuk oleh proses-proses sosial. Begitu memperoleh wujudnya, ia dipelihara, dimodifikasi, atau malahan dibentuk ulang oleh hubungan-hubungan sosial. ${ }^{11}$

7 Peter L. Berger dan Thomas Luckmann, 34.

8 Peter L Berger, Langit Suci: Agama Sebagai Realitas Sosial (Jakarta: LP3ES, 1991), 11-14.

9 Nur Syam, Islam Pesisir (Yogyakarta: LKiS Pelangi Aksara, 2005), 44.

${ }^{10}$ Peter L. Berger dan Thomas Luckmann, Tafsir Sosial Atas Kenyataan: Sebuah Risalah Tentang Sosiologi Pengetahuan, 188.

${ }^{11}$ Peter L. Berger dan Thomas Luckmann, 248. 


\section{Kajian Sosiologis-Historis Ibn Kholdun}

Penelitian ini akan mengkaji sejarah secara kronologis mulai dari Arab praIslam sampai era modern ini. Karena keterbatasan ruang lingkup, maka akan diambil poin-poin penting terhadap sumber-sumber sejarah yang mendukung terhadap hasil penelitian Secara epistemologi, kronologi berasal dari bahasa Yunani, khronos yaitu waktu dan logos yang artinya ilmu. Kronologis yaitu ilmu yang mempelajari peristiwa-peristiwa sejarah sesuai urutan waktu terjadinya, secara time line dari awal hingga akhir. Untuk menggambarkan urutan peristiwa secara runtut, mulai dari tahun yang termuda sampai tahun yang tua. Ini adalah hal yang umumya dipakai oleh para peneliti sejarah, agar memperoleh gambaran atau kondisi masa lalu secar komprehensif dan utuh.

Awal mula kajian sosio-historis dalam dunia modern digagas oleh sosiologiwan Amerika Serikat Imanuel Wallerstein yang mencoba memperluas penyelidikannya hingga jauh ke masa silam, khususnya tentang Ekonomi Dunia Kapitalis. Terdapat tiga tokoh besar ahli sosiologi yang juga sangat konsep terhadap sejarah, seperti :Pareto, Durkheim, dan Weber. Buku Vilfredo Pareto, Treatise on General Sociology (1916) banyak berbicara tentang sejarah Athena, Sparta, dan Romawi klasik dengan mengambil contoh-contoh sejarah Itali Abad Pertengahan.

Emile Durkheim, yang dikenal sebagai tokoh Sosiologi sebagai ilmu dengan teorinya "social fact", yang berusaha memisahkan Sosiologi dari hegemoni Filsafat, dan Psikologi. Dia merasa perlu belajar sejarah kepada Fustel de Coulanges. Bahkan salah satu bukunya itu dipersembahkan untuk Coulanges, serta dia juga menulis monograf sejarah pendidikan Prancis. Kemudian Max Weber sosiolog yang memiliki wawasan luas tentang sejarah, ia sebelum melakukan studi untuk bukunya The Protestan Ethic and the Spirit of Capitalism (1904-1905), sebelumnya ia telah menulis tentang Perniagaan Abad Pertengahan serta Sejarah Pertanian zaman Romawi kuno.

Perubahan paradigma ini beranggapan bahwa dapat diingkari tanpa bantuan kerangka konseptual dari ilmu-ilmu sosial, gejala politik, ekonomi, psikologi, budaya, geografi, sukar dianalisis dan dipahami proses-prosesnya. Kombinasi antar pelbagai perspektif akan mampu mengekstrapolasikan interdependensi antara pelbagai aspek kehidupan yang lebih lanjut kajian ini dikenal sebagai kajian interdisipliner. Dalam hal ini sejarawan tidak langsung berurusan dengan kausalitas, akan tetapi lebih banyak dengan kondisi-kondisi 
dalam pelbagai dimensinya. ${ }^{12}$

Ketika kebanyakan sejarawan memikirkan sejarah menurut kehendak Tuhan, Ibn Khaldun, intelektual asal Arab, berusaha mengenali faktor-faktor penyebab dalam proses sejarah. Ibn Khaldun (1332-1406) lahir di Tunis, keturunan bangsawan yang memang banyak melahirkan sarjana dan tokoh politik ternama. Ibn Khaldun sendiri menghabiskan sebagian besar masa hidupnya dalam kegiatan politik. Karena itu ia mampu meneliti kekacauan politik di Afrika Barat Laut yang mulai menyusut. Ibn Khaldun dalam hidupnya sedang berhadapan perpecahan duania Islam, dan ia memutuskan untuk menerangkan sebab-sebabnya.

Penjelasan sejarah atau pola perubahan sosial ini terkandung dalam karyanya Muqaddimah, suatu bab pendahuluan dari karya sejarahnya yang terkenal itu. Karangannya itu diberi judul "Buku Pelajaran dan Arsip Sejarah Kuno dan Tahap-tahapnya”. Karya ini menerangkan peristiwa politik dunia Arab, Non-Arab, Barbar dan Penguasa Tertinggi yang sezaman dengannya. Muqaddimah Ibn Khaldun meneliti berbagai faktor yang terlihat dalam perubahan sosial. Ibn Khaldun melihat ada pengaruh lingkungan fisik terhadap manusia, bentuk-bentuk organisasi sosial primitif dan modern, hubungan antar-kelompok, dan berbagai fenomena kultural (kesenian, kerajinan, ilmu pengetahuan dsb). Dengan kata lain, ia tidak hanya membuat suatu kemajuan yang berani dalam mencoba memastikan faktor-faktor penyebab perubahan: tetapi ia juga mengakui ada faktor lain penyebab perubahan. Ibn Khaldun memperkenalkan dan menggunakan 6 prinsip yang menjadi landasan sosiologi, yaitu:

a. Fenomena sosial mengukuti pola-pola yang sah menurut hukum.

b. Hukum-hukum proses sosial harus ditemukan melalui pengumpulan banyak data dan dengan mengamati hubungan antara berbagi variabel.

c. Hukum-hukum perubahan itu berlaku pada tingkat kehidupan masyarakat (bukan pada tingkat individual).

d. Masyarakat ditandai oleh perubahan.

e. Hukum-hukum yang berlaku terhadap perubahan itu bersifat sosiologis, bukan bersifat biologis atau bersifat alamiah.

f. Hukum-hukum sosial yang serupa, berlaku dalam berbagai masyarakat yang serupa strukturnya.

${ }^{12}$ Dwi Susanto, "Pengantar Ilmu Sejarah," Surabaya: UIN Sunan Ampel Surabaya, 2014, 12729. 
Ibn Khaldun kemudian membangun teorinya atas premis yang menyatakan bahwa manusia adalah makhluk sosial. "Organisasi sosial manusia adalah penting". Ini diungkapkannya secara filosofis bahwa pada hakekatnya manusia adalah makhluk politik. Teori itu mencoba menerangkan kesuksesan orang Badui merobohkan sejumlah peradaban di Afrika. Ibn Kholdun menemukan satu kata kunci, yang ia sebut Ashobiyah atau solidaritas.

Ashobiyah adalah aspek penting kehidupan Badui dalam teori Khaldun. Kemampuan manusia yang memiliki ashobiyah yang tinggi ini besar kemungkinan akan menaklukan kesatuan lain yang kurang memilikinya. Ikatan kekeluargaan dalam suku Badui menciptakan ashobiyah. Diantara pemikiran mendalam dari karyanya adalah sebagi berikut : 1 . Metode historis menawarkan pendekatan terbaik untuk memahami perubahan sosial; 2. Faktor yang menyebabkan perubahan sosial banyak dan beraneka macam; 3 . Bentukbentuk organisasi sosial yang berbeda, mmenciptakan tipe kepribadian yang berbeda pula. 4. Konflik adalah mekanisme mendasar dari perubahan. 5. Perubahan cendrung merembes, terjadi di semua institusi sosial. ${ }^{13}$

\section{PEMBAHASAN}

\section{Islam Masa Nabi, Kajian Eksternalisasi}

Misi utama ajaran Islam adalah membebaskan manusia dari berbagai bentuk anarki dan ketidakadilan. Rahmat dalam Islam dalam artian menentang segala hal yang tidak sesuai dengan sifat-sifat kemanusiaan (humanisme). Kita lihat problem-problem ketidakadilan masyarakat Arab pra Islam yang disebut sebagai zaman Jahiliyah. Ketidakadilan itu berwujud perbudakan, eksploitasi wanita, wanita yang tidak mendapatkan harta waris, penguburan hidup-hidup bayi, menggunakan hukum rimba dan sebagainya. Lalu Islam datang dan mengubah ketidakadilan semua itu, ada yang sifatnya dekonstruksi dan ada yang hanya rekonstruksi, dengan prinsip "al-Muhafadhotu 'ala qadimi al-Shalih wa al-Akhdzu bi al-Jadid al-Ashlah" (memelihara tradisi Arab Pra Islam yang baik dan mengambil tradisi baru berupa ajaran Islam yang lebih baik).

Nilai-nilai baik yang beredar dalam Arab Pra Islam semisal setia kawan, dermawan, patriotisme tetap dipertahankan setelah masuknya Islam (rekonstruksi) dan ditambah nilai-nilai baru dari Islam seperti kesetaraan gender dan penghargaan HAM mengganti kebiasaan-kebiasaan Arab tentang ekslpoi-

\footnotetext{
${ }^{13}$ Gideon Repi, “Teori-Teori Sosiohistoris,” https://www.slideshare.net/gideonrepi/teoriteori.
} 
tasi wanita dan perbudakan (dekonstruksi). ${ }^{14}$ Nilai-nilai rahmat dalam Islam tersebut dapat kita gali dari Islam masa Rasulullah. Misalnya dalam piagam madinah Rasul mengajarkan nilai-nilai kemanusiaan, persatuan, keadilan, kedamaian, kebebasan memeluk agama, persaudaraan antar agama, toleransi, keadilan, tidak membeda-bedakan (diskriminasi) dan menghargai kemajemukan. Term-term tersebut banyak ditemukan juga dalam nash Al-Qur'an dan Hadist.

Islam Rahmatan lil'alamin juga bisa kita lihat di Madinah. Madinah atau dahulunya bernama Yastrib merupakan kota yang mempunyai tradisi yang berbeda dengan Makkah. Pluralitas dan keberagaman lebih kompleks di Yastrib daripada di Makkah. Rasul bersama masyarakat Yastrib membuat nota kesepakatan (perjanjian) untuk hidup bersama dengan komunitas lain yang berbeda, sebagai sebuah masyarakat pluralistik yang mendiami wilayah yang sama, melalui Piagam Madinah atau yang dikenal Saqifah Yastrib. Dengan dasar ini, negara dan masyarakat Madinah yang dibangun oleh Nabi Muhammad merupakan negara dan masyarakat yang kuat. Peristiwa hijrah telah menciptakan keberagaman penduduk Madinah. Penduduk Madinah tidak terdiri dari suku Aus, Khazraj, dan Yahudi, tetapi Muhajirin Quraisy dan suku-suku Arab lain yang datang dan hidup bersama mereka di Madinah. Nabi menghadapi realitas pluralitas, karena struktur masyarakat Madinah yang baru dibangun terdapat beragam agama yaitu Islam, Yahudi, Kristen, Sabi'in dan Majusi, dan ada juga golongan yang tidak bertuhan (atheis) dan bertuhan banyak (polytheists). Struktur masyarakat yang pluralistik ini dibangun oleh Nabi melalui kesepakatan bersama antar suku dan komunitas lain yang disebut Saqifah Yastrib.

Dalam Saqifah Yastrib ini Nabi Muhammad bersama masyarakat Madinah membangun secara bersama wawasan kebebasan, dibidang ekonomi, agama, serta tanggung jawab sosial dan politik hidupp berdampingan secara aman dan damai. Dalam Piagam tersebut juga menempatkan hak-hak individu yaitu kebebasan memeluk agama, persatuan dan kesatuan, persaudaraan (al-ukhuwwah) antar agama, perdamaian dan kedamaian, toleransi, keadilan (al-adalab), tidak membeda-bedakan (diskriminasi) dan menghargai kemaje-

${ }^{14}$ Muhammad Harfin Zuhdi, "VISI ISLAM RAHMATAN LIL 'ALAMIN," AKADEMIKA: Jurnal Pemikiran Islam 16, no. 2 (2011): 1. Lihat juga Khoirunnisaa Khoirunnisaa, "Pendidikan Agama Sebagai Komponen Dasar Dalam Pembentukan Manusia Yang Berkualitas," An-Nuha : Jurnal Kajian Islam, Pendidikan, Budaya dan Sosial 4, no. 1 (14 Juli 2017): 93-104. https://ejournal.staimadiun.ac.id/index.php/annuha/article/view/168/0 
mukan". 15

Institusi "Saqifah Yastrib" yang berjumlah 47 pasal itu ${ }^{16}$, secara formal mengatur hubungan sosial antara komponen masyarakat, yaitu: Pertama, antara sesama muslim, walau berbeda suku, namun satu ummat (ummatan wahidab) Kedua, hubungan antara komunitas muslim dengan non muslim didasarkan pada prinsip berkehidupan yang baik, saling membantu ketika diserang musuh, membela yang teraniaya, saling menasihati dan menghormati kebebasan beragama. Secara umum, banyak nilai-nilai soaial lain yang terkandung dalam Saqifah Yastrib.

Dari Saqifah Yastrib ini, setidaknya ada dua nilai dasar yang tertuang sebagai dasar atau fundamental dalam mendirikan dan membangun negara Madinah, yaitu: Pertama, prinsip kesederajatan dan keadilan (almusawwah wal'adalab). Kedua, inklusivisme atau keterbukaan. Kedua prinsip ini, ditanamkan dalam bentuk beberapa nilai humanis-universal lainnya, seperti: konsistensi (itidal), seimbang (tawazun), moderat (tawasut) dan toleransi (tasamuh). Kesemuanya menjadi landasan ideal sekaligus operasional dalam menjalin hubungan sosial kemasyarakatan yang mencakup semua aspek kehidupan, baik politik, ekonomi, maupun hukum. ${ }^{17}$

Wajah Islam yang rahmat inilah, yang dibentuk oleh Nabi Muhammad di Madinah kemudian bergeser di kemudian hari pasca meninggalnya Rasulullah. Peneliti menemukan sebuah lompatan atau patahan sejarah, jati diri Islam saat ini yang tidak sesuai dengan masa lalu. Kita akan melihat perubahan wajah Islam yang rahmat ini menjadi wajah konflik yang ekstrim, melalui uaraiaburaian pembahasan selanjutnya.

\section{Islam Pasca Nabi, Objektivitas dan Ashobiyah Bangsa Arab}

Pasca meninggalnya Nabi Muhammad saw, wajah Islam yang Rahmatan lil-áalamin ter-objektif dan bertemu dengan bahan baku utama yaitu jati diri Bangsa Arab. Bangsa Arab yang punya ciri khas. pada masa lalunya sering

${ }^{15}$ Masykuri Abdillah, "Gagasan dan Tradisi Bernegara dalam Islam: Sebuah Perspektif Sejarah dan Demokrasi Modern,” Tashwirul Afkar, no. 7 (2000): 97. dan J. Suyuthi Pulungan, Prinsip-prinsip pemerintahan dalam piagam Madinah ditinjau dari pandangan al-Qur'an (RajaGrafindo Persada, 1994), 68.

${ }^{16}$ Ahmad Sukardja, Piagam Madinah dan Undang-Undang Dasar 1945: kajian perbandingan tentang dasar hidup bersama dalam masyarakat yang majemuk (Penerbit Universitas Indonesia, 1995), 47-57.

${ }^{17}$ Hawwin Muzakki dan Khoirul Mudawinun Nisa', Sejarah Peradaban Islam Periode Klasik Modern (Ponorogo: CV Nata Karya, 2017), 30-31. 
hidup berpindah-pindah, dengan cuaca gurun yang panas dan terbatasnya sumber daya alam baik air maupun makanan yang lain. Jiwa-jiwa petarung, pemberani, serta sering mengunggulkan sukunya, watak itulah yang nantinya juga sangat berpengaruh besar terhadap pemahaman ajaran Islam di masyarakat seluruh dunia ${ }^{18}$ dan naik turunnya sebuah peradaban Islam. Ibn Kholdun menyebutnya dengan istilah ashobiyah (fanatik kesukuan).

Kemunculan Islam berwajah ideologi, dimulai dari faktor politik yang terjadi pasca meninggalnya khalifah Utsman bin Affan yang mengakibatkan penolakan Mu'awiyah bin Abi Sofyan (Gubernur Damaskus masa itu) terhadap kekhalifahan yang baru yaitu Ali bin Abi Thalib. Gesekan kedua kubu tersebut memunculkan perang shiffin dengan masing-masing pendukungnya yang berakhir dengan arbitrase atau tabkim. Pendukung Ali bin Abi Thalib terpecah menjadi dua kubu yaitu syiah (pendukung Ali) dan Khawarij (yang tidak mendukung Ali). Dari sanalah, persoalan ideologis yang pertama kali muncul dan ekstrimitas ideologi tersebut semakin berkembang pesat dan banyak jumlahnya, semisal syiah, asy'ariyah, mu'tazilah, Ikhwanul Muslimin, Jamaah Tabligh dan sebagainya. ${ }^{19}$

Sosiolog Islam, Ibn Khaldun menganalisis adanya pengaruh ashobiyah terhadap banyaknya ideologi-ideologi yang menyebar saat ini. Hal tersebut penulis tunjukkan, agar pembaca mengetahui bagaimana proses pelembagaan Islam ideologis, yang berjalan bersama dengan ciri ashobiyah Bangsa Arab. Ibn Kholdun menyebutkan moral badui dan berperadaban, terbagi ke dalam dua macam; datang secara alami dan muncul dengan direkayasa. Menurutnya, masyarakat badui lebih memiliki sifat pemberani ketimbang kalangan masyarakat kota. Ibn Khaldun menganalisa juga tentang "pengaruh iklim terhadap moral manusia." Wilayah yang diduduki oleh orang-orang dengan udara panas seperti Sudan dan negara Arab, biasanya mereka kurang berhati-hati dan banyak bergembira. Begitu juga dengan masyarakat yang berasal dari teluk. Sedangkan penduduk yang wilayahnya kering biasanya mereka mempunyai tabiat selalu merasakan kesedihan. Sebab utamanya, kemungkinan -masih menurut pandangannya- karena mereka tinggal di wilayah dan daerah yang iklimnya bisa mempengaruhi moral mereka. ${ }^{20}$

\footnotetext{
${ }^{18}$ Arab juga punya "Nalar Arab" yang dikritik oleh Abid al-Jabiri karena kecenderungannya menggunakan nalar bayani (tekstualis) dengan ciri metode Qiyas.

${ }^{19}$ W. Montgomery Watt, Pemikiran Teologi dan Filsafat Islam, ed. oleh Umar Basalim (Jakarta: P3M, 1987), 6-7.

20 Abdurrahman Kasdi, "PEMIKIRAN IBNU KHALDUN DALAM PERSPEKTIF
} 
Arab Badui terbiasa mempertahankan diri dari musuh dan tantangan yang setiap saat menghantui. Begitu juga dengan alam yang tidak bersahabat. Mereka tidak pernah melepaskan senjatanya, karena setiap saat bahaya akan mengancam. Dengan pengalaman ini, bangsa Arab menurut Ibn Khaldun mampu merebut kekuasaan dari pihak lain dengan 'ashabiyahnya. Kondisi di atas, menurut Ibn Khaldun semakin lama mengalami pergeseran, dengan bergantinya waktu. Struktur masyarakat Arab juga mengalami perubahan berdasarkan perubahan orientasi dan sosiologi. Perubahan yang terjadi dalam masyarakat, bukanlah merupakan pengaruh dari luar, melainkan merupakan reaksi yang timbul dalam intern masyarakat yang menjadi tabiatnya. ${ }^{21}$

Berbicara lebih lanjut mengenai ashobiyah atau watak peradaban bangsa Arab, fenomena yang muncul ketika masa menjelang kelahiran Rasulullah, disebut oleh Philip K. Hitti sebagai ayyam al-Arb (Hari-hari orang Arab). ayyam al-Arb merujuk pada pertarungan antar suku demi mempertahankan diri, hidup dan kehidupan sukunya, biasanya persoalan perebutan hewan ternak, padang rumput atau mata air. Pertikaian ini mengakibatkan seringnya terjadi peperangan, perampokan dan penyerangan. Meskipun orang Badui siap untuk berperang, namun tidak serta merta berani mati, bukan seperti yang sering kita dengar melalui buku sejarah orang Arab yang haus darah dan kejam. Jadi, ayyam al-Arb merupakan cara alami orang Badui untuk mengendalikan populasi penduduk yang hidup dalm semi kelaparan, serta menjadikan peprangan sebagai jati diri serta watak sosial yang nnati juga berlanjut, atau melekat pasca meninggalnya Rasulullah SAW. ${ }^{22}$

Kemampuan manusia yang memiliki ashobiyah yang tinggi ini besar kemungkinan akan menaklukan kesatuan lain yang kurang memilikinya. Ikatan kekeluargaan dalam suku Badui menciptakan ashobiyah. Karena dengan ikatan kekeluargaan, manusia memiliki dorongan alamiah untuk melindungi kerabat mereka diserang atau penindasan pihak lain. Agama penting, karena agama menekan sifat ganas orang Badui. Singkatnya karena agama, kelompok yang berorientasi kekeluargaan yang hidup dibawah kondisi lingkungan yang keras, menyebabkan orang Badui tampil seperti gerombolan Jenghis Khan, zalim, perkasa dan ingin serta mampu menghancurkan tiap musuhnya.

Ibn Kholdun semakin menguatkan argumen penulis bahwa Islam ideo-

SOSIOLOGI DAN FILSAFAT SEJARAH," Fikrah 2, no. 1 (2014): 17.

${ }^{21}$ Kasdi.

${ }^{22}$ Philip K. Hitti, History of The Arabs, from the Earliest Times to the Present, trans. oleh R. Cecep Lukman Yasin dan Dedi Slamet Riyadi (Jakarta: Serambi Ilmu Semesta, 2010), 110. 
logis terobjektivitas dalam ashobiyah bangsa Arab yang nantinya tampak dari dinasti-dinasti yang muncul karena persamaan suku, semisal dinasti Umayyah, dinasti Abbasiyah, dinasti Fatimiyah sehingga memunculkan konflik ekstrimitas yang terlembaga dalam aliran seperti asy'ariyah, mu'tazilah, Ikhwanul Muslimin, Hizbut Tahrir, dan lainnya,

\section{Islam Pasca Nabi, Kajian Internalisasi}

Pasca kenabian, ideologi-ideologi ashobiyah yang menjadi ciri khas bangsa Arab, terinternalisasi dalam kelembagaan secara formal maupun non formal dan menjadi mainstream bagi tatanan baru bagi seluruh aspek dunia. Era modern ini, Islam ideologis sudah menjelma dalam berbagai bentuk dengan banyak varian dan macamnya. Hal ini mengingatkan kita pada hadist tentang terpecahnya umat Islam menjadi beberapa golongan. Berikut salah satu hadist yang memberitakan hal tersebut, yang diriwayatkan oleh Abu Dawud dalam kitab as-Sunnah, I-Bab Syarhus Sunnah no. 4596

Hadits Abu Hurairah Radhiyallahu 'anhu

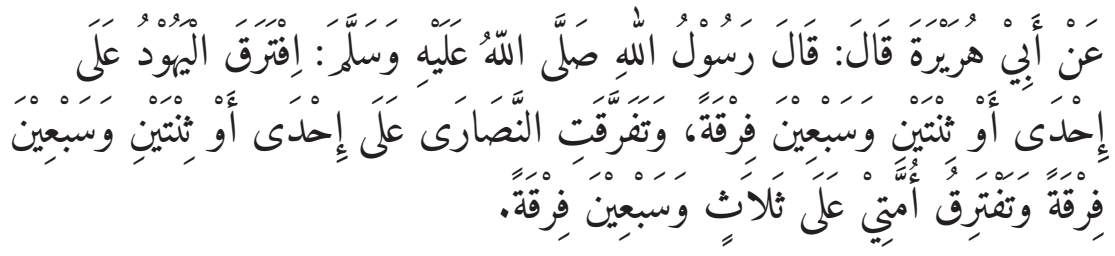

Dari Abu Hurairah Radhiyallahu 'anhu, ia berkata: "Rasulullah Shallallahu 'alaihi wa sallam telah bersabda, 'Kaum Yahudi telah terpecah menjadi tujuh puluh satu (71) golongan atau tujuh puluh dua (72) golongan, dan kaum Nasrani telah terpecah menjadi tujuh puluh satu (71) atau tujuh puluh dua (72) golongan, dan ummatku akan terpecah menjadi tujuh pulub tiga (73) golongan.

Islam pasca kenabian hadir dengan ideologi-ideologi yang terkurung dalam "penjara" kebenaran dalam struktur kelembagaan sebuah aliran. Lantas, tidak heran jika masing-masing aliran membenarkan golongannya sendiri dengan menyandarkan kepada alasan logis beserta dalilnya. Hal tersebut berakibat buruk terhadap penyerangan aliran tertentu, yang berlainan dengannya, tentunya dengan argumen logis beserta dalilnya pula. Islam yang hadir di era pasca kenabian ini muncul dengan berbagai wajah dan simbol-simbol yang mengikat. Misalnya: Islam harus hadir dalam setiap tatanan pemerintahan, maka lahirlah konsep politik dalam Islam bahwa harus memakai sistem 
Khilafah, sedangkan pemerintahan yang demokrasi dianggap kafir dan juga sesat. Islam harus menegakan hukum sesuai syariah yang berlaku seperti potong tangan dan rajam, sedangkan penggunaan hukum positif dan penjara merupakan bid'ah dan tidak ada pada zaman rasul, dan sebagainya.

Berikut bagan mengenai kajian eksternalisasi, objektivasi dan internalisasi dalam perspekrif teori Peter L. Berger yang terjadi masa kenabian dan pasca kenabian.

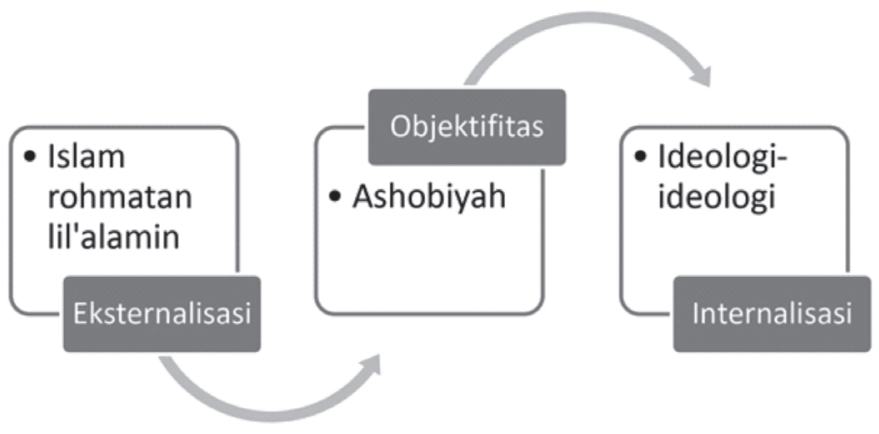

Gambar 1. Proses Konstruksi Sosial Masa Nabi-Pasca Nabi

\section{Islam Nusantara}

Ajaran Islam dalam kaca mata universal, Islam dikatakan agama yang sering konflik secara intern maupun ekstern, Islam dikatakan sebagai agama teroris yang sering membuat gaduh masyarakat dunia, Islam dikatakan agama yang tradisional dan tidak menerima modernitas, dan sebagainya. Kajian sosiologis Peter L. Berger mengatakan bahwa ada pengaruh konstruksi masyarakat terhadap ajaran Islam. Islam menemukan solusi dari tuduhan-tuduhan negatif tersebut dari lokal. Islam lokal menjadi sebuah solusi jawaban mengenai perpecahan di antara umat Islam. Islam lokal ditemui sebagai basis moderat, plural dan damai. Seperti Islam di Indonesia, dengan berbagai suku, ras, bangsa dan agama.

Islam Indonesia (Islam Nusantara) menemukan harmoni dan kedamaian dalam kehidupannya. Setiap orang hidup berdampingan rukun, damai dalam menjalankan setiap aktivitas kemanusiaannya. Dalam hidup, masyarakat di Indonesia tidak lagi memikirkan agamanya apa? Sukunya mana? Atau dari golongan kaya maupun bukan? Semua bersatu padu dan bergotong royong untuk kemajuan negara Indonesia dengan semboyan Bhinneka Tunggal Ika (Berbeda-beda, tetapi tetap Satu Jua).

Islam Nusantara mempunyai ciri-ciri yang khas dan beda dengan Islam 
transnasional. Ciri khas tersebut diambil dari tiga hal penting. Pertama, karakter bangsa yang salah satunya dipengaruhi oleh etika jawa. Kedua, masuknya Islam ke Indonesia melalui jalan damai, seperti yang telah dilakukan oleh wali songo diantaranya melalui kesenian maupun pernikahan. Ketiga, sejarah masa lampau tentang Indonesia antara agama Hindu dan Budha yang hidup saling berdampingan, berinteraksi dan berakulturasi.

\section{Islam Nusantara, Kajian Eksternalisasi}

Dalam penyebaran Islam di Nusantara terdapat kesimpulan beberapa strategi yang dilakukan, sehingga Islam lebih mudah diterima dibandingkan dengan agama lain. Penyebaran Islam yang dilakuakn tersebut lewat jalan damai dan tanpa paksaan. Diantara strategi penyebaran islam tersebut adalah:

Pertama, melalui jalur perdagangan. Para penyiar agama Islam menyebarkan ajarannya melalui perdagangan dengan melakukan interaksi dari negeri seperti Persia, Arab, Anak Benua India, Melayu, dan Cina yang berlangsung lama, membuat komunitas Islam semakin berwibawa, dan pada akhirnya membentuk masyarakat muslim.

Kedua, melalui jalur dakwah bi al-häl yang dilakukan oleh para muballigh yang merangkap tugas menjadi pedagang. Proses dakwah tersebut pada mulanya dilakukan secara individual. Mereka melaksanakan kewajiban-kewajiban syari'at Islam dengan memperhatikan kebersihan, dan dalam pergaulan mereka menampakan sikap sederhana.

Ketiga, melalui jalur perkawinan, yaitu perkawinan antara pedagang Muslim, muballigh dengan anak bangsawan Nusantara. Berawal dari kecakapan ilmu pengetahuan dan pengobatan yang didapati dari tuntunan hadits Nabi Muhammad Saw. ada di antara kaum muslim yang berani memenuhi sayembara yang diadakan oleh raja dengan janji, bahwa barang siapa yang dapat mengobati puterinya apabila perempuan akan dijadikan saudara, sedangkan apabila laki-laki akan dijadikan menantu. Dari perkawinan dengan puteri raja lah Islam menjadi lebih kuat dan berwibawa.

Keempat, melalui jalur pendidikan. Setelah kedudukan para pedagang mantap, mereka menguasai kekuatan ekonomi di bandar-bandar seperti Gresik. Pusat-pusat perekonomian itu berkembang menjadi pusat pendidikan dan penyebaran Islam. Pusat-pusat pendidikan dan dakwah Islam di kerajaan Samudra Pasai berperan sebagai pusat dakwah pertama yang didatangi pelajarpelajar dan mengirim muballigh lokal, di antaranya mengirim Maulana Malik 
Ibrahim ke Jawa. ${ }^{23}$

Kelima, melalui jalur kultural. Awal mulanya kegiatan islamisasi selalu menghadapi benturan dengan tradisi Jawa yang banyak dipengaruhi HinduBudha. Setelah kerajaan Majapahit runtuh kemudian digantikan oleh kerajaan Islam. Di Jawa Islam menyesuaikan dengan budaya lokal sedang di Sumatera adat menyesuaikan dengan Islam. ${ }^{24}$

Islam terus berkembang dan menyebar dari masa ke masa hingga sekarang melalui tahapan-tahapan dan jasa para mubaligh. Di Pulau Jawa, para ulama penyebar Islam tergabung dalam Wali Songo (Sembilan Wali), yang terdiri atas Maulana Malik Ibrahim (Sunan Gresik), Raden Rahmat (Sunan Ampel), Maulana Makdum Ibrahim (Sunan Bonang), Raden Sahid (Sunan Kalijaga), Syarif Hidayatullah (Sunan Gunung Jati), Raden Qasim (Sunan Drajad), Raden Paku (Sunan Giri), Ja'far Shadiq (Sunan Kudus), Raden Umar Said (Sunan Muria)..$^{25}$

\section{Islam Nusantara, Kajian Objektivitas (Pluralitas dan Etika Jawa)}

Penulis menemukan setidaknya ada dua sumber objektivitas Islam Nusantara yang berasal dari masyarakat Indonesia, yaitu ajaran pluralitas dan etika jawa. Pertama, ajaran pluralitas yang didapatkan dari nenek moyang terdahulu bangsa Indonesia. Indonesia dalam kacamata sejarah panjangnya, tentu mendapat pengaruh besar dari agama Hindu dan Budha sebelum masuk dan berkembangnya agama Islam. Hindu dan Budha pada masa itu, juga hidup berdampingan secara damai di Nusantara, yang diabadikan dalam semboyan bangsa "Bhinneka Tunggal Ika".

Pertama, Bhinneka Tunggal Ika itu merupakan sebuah karya sastra agama yang diambil dari kitab Sutasoma karya Mpu Tantular, dengan kalimat lengkapnya sebagai berikut: Rwaneka dhatu winuwus Buddha Wiswa, Bhinnêki rakwa ring apan kena parwanosen, Mangka ng Jinatwa kalawan Siwatatwa tunggal, Bhinnêka tunggal ika tan hana dharma mangrwa. Konon agama Buddha, Hindu dan Siwa merupakan ajaran zat yang berbeda, namun nilai-

${ }^{23}$ Hawwin Muzakki dan Khoirul Mudawinun Nisa, "Basis Transformasi Tradisi Pesantren Salaf di Era Modern (Kajian Semiotika Barthes dan Dekonstruksi Derrida)," QALAMUNA: Jurnal Pendidikan, Sosial, dan Agama 12, no. 1 (2020): 91-105.

${ }^{24}$ Achmad Syafrizal, "SEJARAH ISLAM NUSANTARA," Islamuna: Jurnal Studi Islam 2, no. 2 (5 Desember 2015): 241-42, https://doi.org/10.19105/islamuna.v2i2.664.

${ }^{25}$ Ashadi Ashadi, "Dakwah Wali Songo Pengaruhnya Terhadap Perkembangan Perubahan Bentuk Arsitektur Mesjid Di Jawa (Studi Kasus : Mesjid Agung Demak)," Nalars 12, no. 2 (31 Juli 2013): 3, https://doi.org/10.24853/nalars.12.2.\%p. 
nilai mengajaran kebenaran Jina (Buddha), Hindu dan Siwa adalah tunggal. Terpecah belah, tetapi satu jualah itu. Artinya tidak ada kerancuan dalam kebenaran. Ajaran luhur peninggalan nenek moyang terdahulu tersebut mengajarkan bangsa Indonesia mengerti betul arti perbedaan dan keberagaman, serta menyelesaikannya dengan jalan damai (persatuan). Islam Nusantara juga terpengaruh ajaran nenek moyang tersebut, karena konstruksi dari masyarakat sekitar.

Kedua, mengenai moral atau etika Jawa yang khususnya berpengaruh terhadap agama Islam. Uniknya, budaya jawa ini semakin meneguhkan identitasnya ketika berinteraksi dengan ajaran lain. Jawa, saat mendapat "serangan" dari budaya hindhu, budha dan Islam, semakin meneguhkan identitasnya dengan banyaknya akulturasi budaya yang terjadi. Munculnya slametan, pitonpiton, islam kejawen, bukti dari itu semua. Memang etika jawa ini muncul dengan prinsip harmoni. Bahagia dalam perspektif jawa bisa tercipta jika terjadi harmoni dalam 3 hal, yaitu: masyarakat, alam dan adi kodrati.

Harmoni terhadap masyarakat misalnya Orang jawa akan menghindari debat, marah-marah ataupun emosi meluap-luap dengan terbuka. Dalam sebuah keputusan, walaupun sejatinya tidak setuju, beberapa orang jawa akan menerima keputusan ketika forum terbuka. Namun, di belakang forum jika ada orang yang tidak setuju, akan melakukan protes berupa rasan-rasan, gosip, atau mengungkapkan alasan ketidaksetujuannya melalui warung kopi maupun perkumpulan yang lain dan juga tindakan-tindakan lainnya. Sehingga seperti falsafah jawa yang memaknai simbol blangkon di kepala, rata di depan namun "mentul" di belakang, dengan maksud menghindari debat terbuka untuk menciptakan harmoni di dalam masyarakat.

Harmoni terhadap alam. Bagaimana masyarakat jawa juga menciptakan kebahagiaan melalui keselarasan dengan alam. Ular sawah bagi pertanian orang jawa bukan merupakan musuh, melainkan sahabat yang harus dipelihara dan dijaga, karena dapat mencegah merebaknya pertumbuhan tikus. Permasalahan alam dicari penyelesaiannya dengan alam, tidak perlu pemakaian racun untuk mengendalikan hama tikus, serta mengurangi pemakaian pupuk konvensional agar serangga-serangga yang dibutuhkan tanaman tetap hiduo. Seperti penyiapan sesajen yang ditaruh di pinggir-pinggir persawahan, untuk menjadi makanan serangga-serangga kecil sehingga tidak mengganggu pertumbuhan padi.

Harmoni terhadap adikodrati (ghoib). Orang jawa mempercayai ada kekuatan lain di luar diri manusia. Sehingga dalam adat istiadatnya memper- 
cayai hal-hal yang adikodrati (ghoib). Adanya sesajen dalam tindakannya, bukan malah mengusir maupun mengganggu mahkhluk ghoib tersebut, memberikan pengertian pada kita bahwa orang Jawa juga memelihara harmoni dengan hal-hal yang ghoib. Pengaruh besar ajaran pluralitas dan etika Jawa di atas menjadikan ajaran Islam Nusantara yang bersifat moderat, plural, rukun dan damai. ${ }^{26}$

\section{Islam Nusantara, Kajian Internalisasi}

Pengaruh objektivitas kondisi plural bangsa Indonesia dan sumber etika dari jawa membuat pemahaman baru tentang agama Islam, yaitu Islam moderat. Kalangan NU menyebutnya sebagai Islam Nusantara, sedangkan Muhammadiah menamakannya Islam berkemajuan, dan MUI mengatakan Islam washathiyyah. Pemahaman moderat menyeru kepada dakwah Islam yang toleran, menentang segala bentuk pemikiran yang liberal dan radikal. Islam yang moderat dalam kehidupan keagamaan, kemasyarakatan, kebangsaan, dan kenegaraan. Sikap moderat adalah bentuk manifestasi ajaran Islam sebagai rahmatan lil 'alamin. Akhirnya memunculkan gagasan moderasi Islam nusantara dengan ciri-ciri atau karakter nilai sebagai berikut: ${ }^{27}$

a. Tawassuth (mengambil jalan tengah), yaitu pemahaman dan pengamalan yang tidak ifrâth (berlebih-lebihan dalam beragama) dan tafrith (mengurangi ajaran agama);

b. Tawâzun (berkeseimbangan), yaitu pemahaman dan pengamalan agama secara seimbang yang meliputi semua aspek kehidupan, baik duniawi maupun ukhrawi, tegas dalam menyatakan prinsip yang dapat membedakan antara inhiraf (penyimpangan) dan ikhtilaf (perbedaan);

c. I'tidâl (lurus dan tegas), yaitu menempatkan sesuatu pada tempatnya dan melaksanakan hak dan memenuhi kewajiban secara proporsional;

26 Franz Magnis Suseno, Etika Jawa: Sebuah Analisa Falsafi tentang Kebijaksanaan Hidup Jawa (Jakarta: Gramedia, 1984), 85, http://www.bukabuku.com/browses/ product/9789794030059/etika-jawa-sebuah-analisa-falsafi-tentang-kebijaksanaan-hidupjawa.html. Lihat juga Musthofa Musthofa, "Islam Nusantara Dalam Tinjauan Tafsir Izwaji," An-Nuba : Jurnal Kajian Islam, Pendidikan, Budaya dan Sosial 5, no. 2 (20 Desember 2018), http://ejournal.staimadiun.ac.id/index.php/annuha/article/view/267.

${ }_{27}$ Afrizal Nur, "Konsep Wasathiyah Dalam Al-Quran;(Studi Komparatif Antara Tafsir AlTahrir Wa At-Tanwir Dan Aisar At-Tafasir)," Jurnal An-Nur 4, no. 2 (2016): 5. Lihat juga Khoirul Mudawinun, "Integrasi Nilai-Nilai Moderasi pada Pendidikan Anak Usia Dini Berbasis Living Values Education (LVE)," dalam Proceedings of Annual Conference for Muslim Scholars, 2018, 726 . 
d. Tasâmuh (toleransi), yaitu mengakui dan menghormati perbedaan, baik dalam aspek keagamaan dan berbagai aspek kehidupan lainnya;

e. Musâwah (egaliter), yaitu tidak bersikap diskriminatif pada yang lain disebabkan perbedaan keyakinan, tradisi dan asal usul seseorang;

f. Syûra (musyawarah), yaitu setiap persoalan diselesaikan dengan jalan musyawarah untuk mencapai mufakat dengan prinsip menempatkan kemaslahatan di atas segalanya;

g. Ishlâh (reformasi), yaitu mengutamakan prinsip reformatif untuk mencapai keadaan lebih baik yang mengakomodasi perubahan dan kemajuan zaman dengan berpijak pada kemaslahatan umum (mashlahah 'ammah) dengan tetap berpegang pada prinsip al-muhafazhah 'ala al-qadimi al-shalih wa al-akhdzu bi al-jadidi al-ashlah (melestarikan tradisi lama yang masih relevan, dan menerapkan hal-hal baru yang lebih relevan);

h. Aulawiyah (mendahulukan yang prioritas), yaitu kemampuan mengidentifikasi hal ihwal yang lebih penting harus diutamakan untuk diimplementasikan dibandingkan dengan yang kepentingannya lebih rendah;

i. Tathawwur wa Ibtikâr (dinamis dan inovatif), yaitu selalu terbuka untuk melakukan perubahan-perubahan sesuai dengan perkembangan zaman serta menciptakan hal baru untuk kemaslahatan dan kemajuan umat manusia;

j. Tahadhdhur (berkeadaban), yaitu menjunjung tinggi akhlak mulia, karakter, identitas, dan integritas sebagai khairu ummah dalam kehidupan kemanusiaan dan peradaban.

Berikut bagan mengenai kajian eksternalisasi, objektivasi dan internalisasi dalam perspekrif teori Peter L. Berger yang terjadi di Nusantara. 


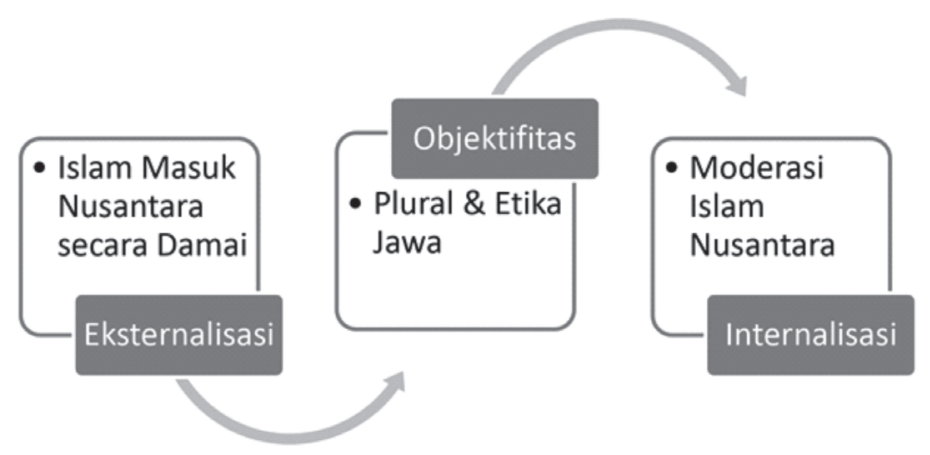

Gambar 2. Proses Konstruksi Sosial Islam Nusantara

Islam Nusantara lahir dengan wajah yang akomodatif, toleran, damai dan pluralism. Wajah Islam Nusantara tersebut dibuktikan dengan dakwah Islam yang tanpa perang, melainkan dengan jalan dakwah, seni, pernikahan, akulturasi budaya dan sekarang hampir seluruh masyarakat Indonesia memeluknya. Artinya, dalam perspektif sejarah masyarakat Indonesia menerima Islam sebagai agama yang tidak berwajah radikal, ekstrim dan fundamental, melainkan agama yang menawarkan toleransi tinggi terhadap perbedaanperbedaan. Sangat rasional ketika masyarakat Indonesia pada waktu itu tidak berpikir panjang untuk memeluk agama Islam.

Untuk menginternalisasi wajah Islam Nusantara yang penuh dengan keindahan toleransi, kita perlu memperkenalkan secara konkrit berbagai macam bentuk perbedaan yang ada di Indonesia, dari mulai agama, suku, budaya, bahasa, ras, golongan, etnis dan sebagainya. Islam Nusantara adalah gambaran agama Islam yang anti terhadap konflik apalagi aksi radikal dan terorisme. Islam dengan wajah yang memposisikan perbedaan sebagai suatu rahmat, sangat relevan dengan karakteristik masyarakat Indonesia dengan Etika Jawanya. Islam Nusantara memiliki akar sejarah sikap akomodatif dan toleran yang kuat dalam tradisi masyarakat Indonesia yang terekam dengan Istilah "Bhineka Tunggal Ika” terdapat dalam kitab Kakawin Sutasoma karangan Mpu Tantular. Islam yang mengajarkan rahmatan lil 'alamin datang pada masyarakat Indonesia yang memiliki sikap toleran sebagai watak dasar suku-suku bangsanya merupakan perpaduan sempurna terwujudnya Islam Nusantara di Indonesia.

\section{KESIMPULAN}

Perubahan wajah Islam yang tadinya rahmatan, menjadi ideologi menggu- 
nakan pembacaan analisis teori kontruksi sosial disimpulkan sebagai berikut: Pertama, secara eksternalisasi Islam di awal pertumbuhannya dan perkembangannya yang disampaikan oleh Nabi Muhammad membawa ajaran rahmatan lil'alamin dengan menghapus nilai-nilai diskriminasi dan ketidakadilan yang bersumber dari tradisi bangsa Arab. Kedua, nilai rohmat tersebut terobjektivikasi oleh sifat khas bangsa Arab yaitu ashobiyah (fanatik kesukuan). Ketiga, sifat ashobiyah bangsa arab tersebut terinternalisasi ke dalam masyarakat melalui ekstrimitas-ekstrimitas, konflik-konflik kepentingan dan kekuasaan dengan corak ideologi yang bervariasi. Lahirlah wajah islam dengan banyak ideologiideologi (jabariyah, qodariyah, mu'tazilah, ikhwanul muslimin, hizbut tahrir, jamaah tabligh, dll) yang menyebar ke seluruh penjuru dunia hingga saat ini.

Pemahaman yang sama menggunakan Teori Konstruksi Sosial oleh Peter L. Berger untuk membaca Islam Nusantara, yang ditemukan oleh penulis mempunyai wajah moderat dan damai. Temuan ini bertujuan untuk mengembalikan Islam yang ideologi menjadi rahmatan lil'alamin kembali. Kajian tentang Islam Nusantara disimpulkan sebagai berikut: Pertama, Islam datang di Indonesia melalui jalan damai dengan saluran pernikahan, perdagangan, kesenian, dakwah, pendidikan dan kultural. Kedua, ajaran Islam akhirnya terobjektivasi oleh masyarakat Indonesia yang plural pada waktu itu dan terpengaruh oleh sumber utama berupa "etika jawa". Sehingga dalam kesehariannya mencintai nilai-nilai moderasi dan menghindari konflik. Ketiga, sifat plural dan menjaga keharmonisan dalam etika jawa tersebut tertanam karakter nilainilai moderasi yaitu: Tawassuth, Tawâzun, I'tidâl, Tasâmuh, Musâwah, Syûra, Ishlâh, Aulawiyah, Tathawwur wa Ibtikâr dan Tahadhdhur. Peneliti menemukan yang tetap dalam Islam adalah sifat damai dan moderat (menjadi penggerak atau ruh) yang ditemukan dalam Islam Masa Nabi dan Islam Nusantara. Sedangkan yang berubah berupa ajaran-ajaran Islam yang mengandung ideologi ekstrimisme, fundamentalis, radikal karena terpengaruh konflik kepentingan tertentu atau keinginan untuk berkuasa, yang terjadi ketika masa perluasan Islam dan munculnya aliran ideologi Islam transnasional. 


\section{DAFTAR PUSTAKA}

Abdillah, Masykuri. "Gagasan dan Tradisi Bernegara dalam Islam: Sebuah Perspektif Sejarah dan Demokrasi Modern." Tashwirul Afkar, no. 7 (2000).

Ashadi, Ashadi. "Dakwah Wali Songo Pengaruhnya Terhadap Perkembangan Perubahan Bentuk Arsitektur Mesjid Di Jawa (Studi Kasus : Mesjid Agung Demak)." Nalars 12, no. 2 (31 Juli 2013): 153467. https:// doi.org/10.24853/nalars.12.2.\%p.

Berger, Peter L. Langit Suci (Agama Sebagai Realitas Sosial). Jakarta: LP3ES, 1991.

Berger, Peter L., dan Thomas Lukhmann. Tafsir Sosial atas Kenyataan. Jakarta: LP3ES, 1990.

Bungin, Burhan. Konstruksi Sosial Media Massa: Kekuatan Pengaruh Media Massa, Iklan Televisi dan Keputusan Konsumen serta Kritik Terhadap Peter L. Berger \& Thomas Luckmann. Jakarta: Kencana, 2010.

Franz Magnis Suseno.Etika Jawa: Sebuah Analisa Falsafitentang Kebijaksanaan Hidup Jawa. Jakarta: Gramedia, 1984. http://www.bukabuku.com/ browses/product/9789794030059/etika-jawa-sebuah-analisafalsafi-tentang-kebijaksanaan-hidup-jawa.html.

Gideon Repi. “Teori-Teori Sosiohistoris." Education, 03:05:32 UTC. https:// www.slideshare.net/gideonrepi/teoriteori.

Harold, Rudy. "Agama dan Pembentukan Realitas dalam Pandangan Peter Ludwig Berger." Cakrawala 5, no. 1 (2016).

Hawwin Muzakki, dan Khoirul Mudawinun Nisa'. Sejarah Peradaban Islam Periode Klasik - Modern. Ponorogo: CV Nata Karya, 2017.

Kasdi, Abdurrahman. "PEMIKIRAN IBNU KHALDUN DALAM PERSPEKTIF SOSIOLOGI DAN FILSAFAT SEJARAH.” Fikrah 2, no. 1 (2014): 17.

Khoirunnisaa, Khoirunnisaa. "Pendidikan Agama Sebagai Komponen Dasar Dalam Pembentukan Manusia Yang Berkualitas.” An-Nuha : Jurnal Kajian Islam, Pendidikan, Budaya dan Sosial 4, no. 1 (14 Juli 2017): 93-104.

M.Poloma, Margaret. Sosiologi kontemporer. Jakarta: Rajawali Press, 1984.

Mudawinun, Khoirul. "Integrasi Nilai-Nilai Moderasi pada Pendidikan 
Anak Usia Dini Berbasis Living Values Education (LVE)." Dalam Proceedings of Annual Conference for Muslim Scholars, 721-730, 2018.

Musthofa Musthofa. "Islam Nusantara Dalam Tinjauan Tafsir Izwaji." AnNuha: Jurnal Kajian Islam, Pendidikan, Budaya dan Sosial 5, no. 2 (20 Desember 2018). http://ejournal.staimadiun.ac.id/index.php/ annuha/article/view/267.

Muzakki, Hawwin, dan Khoirul Mudawinun Nisa. "Basis Transformasi Tradisi Pesantren Salaf di Era Modern (Kajian Semiotika Barthes dan Dekonstruksi Derrida)." QALAMUNA: Jurnal Pendidikan, Sosial, dan Agama 12, no. 1 (2020): 91-105.

Nur, Afrizal. "Konsep Wasathiyah Dalam Al-Quran;(Studi Komparatif Antara Tafsir Al-Tahrir Wa At-Tanwir Dan Aisar At-Tafasir)." Jurnal An-Nur 4, no. 2 (2016).

Peter L. Berger, dan Thomas Luckmann. Tafsir Sosial Atas Kenyataan: Sebuah Risalah Tentang Sosiologi Pengetahuan. Jakarta: LP3ES, 1990.

Philip K. Hitti. History of The Arabs, from the Earliest Times to the Present. Diterjemahkan oleh R. Cecep Lukman Yasin dan Dedi Slamet Riyadi. Jakarta: Serambi Ilmu Semesta, 2010.

Pulungan, J. Suyuthi. Prinsip-prinsip pemerintahan dalam piagam Madinah ditinjau dari pandangan al-Qur'an. RajaGrafindo Persada, 1994.

Sukardja, Ahmad. Piagam Madinah dan Undang-Undang Dasar 1945: kajian perbandingan tentang dasar hidup bersama dalam masyarakat yang majemuk. Penerbit Universitas Indonesia, 1995.

Susanto, Dwi. "Pengantar Ilmu Sejarah." Surabaya: UIN Sunan Ampel Surabaya, 2014.

Syafrizal, Achmad. "SEJARAH ISLAM NUSANTARA." Islamuna: Jurnal Studi Islam 2, no. 2 (5 Desember 2015): 235-53. https://doi. org/10.19105/islamuna.v2i2.664.

Syam, Nur. Islam Pesisir. Yogyakarta: LKiS Pelangi Aksara, 2005.

W. Montgomery Watt. Pemikiran Teologi dan Filsafat Islam. Disunting oleh Umar Basalim. Jakarta: P3M, 1987.

Zuhdi, Muhammad Harfin. "VISI ISLAM RAHMATAN LIL 'ALAMIN." AKADEMIKA: Jurnal Pemikiran Islam 16, no. 2 (2011): 149-70. 